\section{Atrial natriuretic pep- tide responses during anaesthesia in patients with refractory cardiomyopathies}

Silas N. Glisson PhD, Glen E. Gutzke MD, Roque Pifarre MD, Tadikonda L.K. Rao MD
In patients with congestive heart failure, the release of atrial natriuretic peptide (ANP) is decreased. This study sought to determine the extent of ANP, sympathetic and haemodynamic responses to acutely increased atrial pressure in patients with cardiomyopathies undergoing orthotopic cardiac transplantation. Haemodynamic variables, plasma ANP, norepinephrine, and epinephrine concentrations were measured in 17 patients at five times before and after induction of anaesthesia using either ketamine $1.5 \mu \mathrm{g} \cdot \mathrm{kg}^{-1}$ or sufentanil $3.6 \pm 0.3 \mu \mathrm{g} \cdot \mathrm{kg}^{-1}$. Preinduction values in the ketamine and sufentanil groups were not significantly different. Compared with preinduction values, increases in mean arterial pressure (26\%), pulmonary capillary wedge pressure (90\%), right atrial pressure (107\%), and heart rate $(24 \%)$ occurred in the ketamine group while cardiac index decreased by $19 \%(P<0.05)$. Haemodynamic variables in the sufentanil group did not change at any of the times studied. Plasma concentrations of atrial natriuretic peptide were not different within or between treatment groups. Following tracheal intubation plasma norepinephrine levels increased by $116 \%$ in the ketamine group $(P<0.05)$, but did not change in the sufentanil group. Plasma norepinephrine concentrations differed significantly between the ketamine and sufentanil groups. There were no differences in epinephrine concentrations in either group. Despite the anticipated haemodynamic

Key words

HEART: failure, transplantation; HORMONES: atrial natriuretic peptide, catecholamines.

From the Departments of Anesthesiology and Thoracic and Cardiovascular Surgery, Loyola University Chicago Medical Center.

Address correspondence to: Dr. Silas N. Glisson, Department of Anesthesiology, Loyola University Chicago Medical Center, 2160 South First Avenue, Maywood, Illinois 60153.

(Dr. Glisson's present address is Dept. of Anesthesia, Northwestem University, 303 E. Chicago Avenue, Chicago, IL 60611.)

Accepted for publication 13th February, 1991. and catecholamine differences found between the keramine and sufentanil groups, the levels of plasma ANP were similar. Based upon these results, it is concluded that ANP exerts little influence in the control of fluid volume or blood pressure in patients with refractory cardiomyopathy.

La libération du peptide natriurétique par l'oreilletle (ANP) diminue chez les patients en insuffisance cardiaque. Celle érude cherche à déterminer l'étendue des réponses sumpathiques et hémodynamiques ainsi que les effets sur l'ANP lors de la dimimution aiguë de la pression auriculaire chez les patients atteints de cardiomyopathies et devant subir une transplantation cardiaque orthotopique. Les données hémodynamiques, l'ANP plasmatique, les concentrations de norépinéphrine et d'épiné. phrine furent mesurées chez 17 patients à cinq temps avant et après l'induction de l'anesthésie avec soit la kéramine $1.5 \mu \mathrm{g}$. $\mathrm{kg}^{-1}$ ou le sufentanil 3,6 $\pm 0,3 \mu \mathrm{g} \cdot \mathrm{kg}^{-1}$. Les valeurs de préinduction dans les groupes kétamine et sufentanil n'éraient pas significativement différentes. Comparativement aux valeurs de préinduction, on a observé une augmentation de la pression artérielle moyenne (26\%), de la pression de l'artère pulmonaire bloquée ( $90 \%)$, de la pression de l'oreillette droite (107\%), et de la fréquence cardiaque (24\%) dans le groupe kétamine alors que $l$ 'index cardiaque a diminué de $19 \%(P<0.05)$. Les données hémodynamiques dans le groupe sufentanil n'ont pas changé en aucun temps durant l'étude. Les concentrations plasmatiques de l'ANP n'étaient pas différentes à l' intérieur du méme groupe ni entre les deux groupes étudiés. Après l'intubation trachéale, le niveau plasmatique de norépinéphrine a augmenté de $116 \%$ dans le groupe kétamine $(P<0.05)$, mais n'a pas changé dans le groupe sufentanil. Les concentrations plasmatiques de norépinéphrine étaient significativement différentes entre les groupes kétamine et sufentanil. Il n'y avait pas de différence quant aux concentrations d'épinéphrine dans les deux groupes. Malgré une différence hémodynamique et des concentrations anticipées de catécholamines entre le groupe kétamine et sufentanil, les niveaux plasmatiques d'ANP étaient similaires. Se basant sur ces résultats, on conclut que l' ANP exerce peu d' influence sur le contrôle du volume liquidien ou la pression artérielle chez les patients atteints de cardiomyopathie réfractaire. 
Atrial natriuretic peptide (ANP) released from atrial myocytes is a vasoactive peptide that primarily acts in regulating urine flow and sodium excretion. ${ }^{1-5}$ In normal subjects, increased atrial pressure causing distension and stimulation of atrial myocytes initiates ANP release. ${ }^{6-7}$ Studies of patients with congestive heart failure (CHF) indicated an elevated resting concentration of plasma ANP but, when compared with normal subjects, the amount of ANP released from atria in response to graded increases in right atrial pressure was reduced. ${ }^{8.9}$ Further, patients with valvular heart disease and dilated cardiomyopathy released only half the amount of ANP in response to increased atrial pressure as did CHF patients. ${ }^{9}$ In experimental studies, atrial tissues of spontaneous hypertensive rats ${ }^{10}$ and Syrian hamsters ${ }^{11}$ with cardiomyopathy showed depletion of ANP. It has been suggested that the secretory mechanism of ANP in patients with CHF is different from normal subjects. ${ }^{9}$

To expand upon these findings, this study was undertaken to measure and evaluate ANP, sympathetic and haemodynamic responses to an acute increase in atrial pressure in patients with refractory cardiomyopathy.

\section{Methods}

Seventeen patients scheduled for orthotopic cardiac transplantation were randomly divided into two treatment groups. Institutional Review Board approval and informed consent were obtained. All patients had terminal heart disease with ejection fractions $<0.27$. The inotropic and vasodilator medications, dobutamine (most patients), amrinone, and nitroglycerin, were continued until the time of induction of anaesthesia. Preoperative medication included morphine and lorazepam. Two iv catheters, a radial artery catheter, and a left internal jugular catheter were inserted under local anaesthesia. A thermodilution pulmonary artery catheter was used to measure cardiac output and right and left side cardiac pressures. Ketamine or sufentanil was administered to consecutive patients in an alternating fashion. No subject was excluded or choice of induction drug altered because of the patient's physical. condition. Nine patients were anaesthetized with ketamine, $1.5 \mathrm{mg} \cdot \mathrm{kg}^{-1}$ iv producing loss of responsiveness. The remaining eight patients were anaesthetized with sufentanil, $3.59 \mu \mathrm{g} \cdot \mathrm{kg}^{-1}$ mean dose with a range of 2.75 to 4.85 . The sufentanil was infused using a diluted 5 $\mu \mathrm{g} \cdot \mathrm{ml}^{-1}$ concentration at the rate of $100 \mu \mathrm{g} \cdot \mathrm{min}^{-1}$ until loss of responsiveness. Muscle relaxation was achieved using vecuronium, 0.11 to $0.30 \mathrm{mg} \cdot \mathrm{kg}^{-1}$. The lungs were ventilated manually with oxygen prior to direct laryngoscopy and intubation. Haemodynamic measurements and blood samples were obtained preinduction (control), preintubation, and at two, five, and ten minutes after intubation. Heart rate (HR), mean arterial pressure
TABLE I Demographics

\begin{tabular}{llc}
\hline & Ketamine group & Sufentanil group \\
\hline Sex M & 8 & 5 \\
F & 1 & 3 \\
Age $(\mathrm{yr})$ & $49.4 \pm 4.5$ NS & $37.3 \pm 5.7$ \\
Height $(\mathrm{cm})$ & $173.1 \pm 5.3 \mathrm{NS}$ & $172.9 \pm 5.9$ \\
Weight $(\mathrm{kg})$ & $69.8 \pm 5.3 \mathrm{NS}$ & $65.9 \pm 5.9$ \\
\hline
\end{tabular}

Mean \pm SEM, NS - not significant.

(MAP), mean pulmonary artery pressure (MPAP), mean pulmonary capillary wedge pressure (PCWP), right atrial pressure (RAP), and cardiac output in triplicate were measured at each time period. Arterial blood samples were analyzed for ANP, norepinephrine (NE) and epinephrine (EPI).

Plasma catecholamines were absorbed onto alumina, eluted with acetic acid, and measured by highperformance liquid chromatography with electrochemical detection as described by Glisson. ${ }^{12}$ Normal plasma NE and EPI values in our laboratory are $150-300$ and $50-150$ $\mathrm{pg} \cdot \mathrm{ml}^{-1}$, respectively. The assay sensitivity is $40 \mathrm{pg} \cdot$ $\mathrm{ml}^{-1}$ plasma with a reproducibility of $7.0 \%$. The ANP was extracted from plasma using C18 Sep Pak ${ }^{\circledR}$ cartridges. Aliquots were assayed for ANP using the Amersham ${ }^{125}$ I ANP radioimmunoassay. Plasma ANP concentrations were determined from a standard curve of known amounts of ANP assayed in parallel with the plasma samples. Normal plasma ANP values in our laboratory are 35-60 $\mathrm{pg} \cdot \mathrm{ml}^{-1}$. The assay sensitivity and reproducibility are $12.0 \mathrm{pg} \cdot \mathrm{ml}^{-1}$ and $11.0 \%$, respectively. Chemistry values have been corrected to reflect $100 \%$ extraction recovery.

The data are presented as the mean \pm SEM. Statistical analysis of the data included repeated measures ANOVA and, when indicated, post hoc testing using paired and unpaired $\mathrm{t}$ tests with Bonferroni's adjustment for multiple comparisons. The ANP, NE and EPI results were analyzed using the Kruskal-Wallis and Mann-Whitney tests. A probability of 0.05 was accepted to indicate a significant difference between the groups.

\section{Results}

Demographic data for the ketamine and sufentanil groups are shown in Table I. Cardiovascular responses (Table II) show that patients in the ketamine group had increases in RAP and PCWP to about twice their control values with HR, MAP and MPAP 20-50\% greater than control $(P<$ 0.05). Cardiac index was decreased following ketamine to a level $19 \%$ below the preinduction value $(P<0.05)$. Among the derived haemodynamic variables an increase was observed in systemic vascular resistance, while the stroke volume index decreased. Plasma NE concentra- 
TABLE II Cardiovascular responses

\begin{tabular}{|c|c|c|c|c|c|c|}
\hline \multirow[b]{2}{*}{ Variable } & \multirow[b]{2}{*}{ Group } & \multirow[b]{2}{*}{ Preinduction } & \multirow[b]{2}{*}{ Preintubation } & \multicolumn{3}{|l|}{ Postintubation } \\
\hline & & & & $2 \min$ & $5 \mathrm{~min}$ & $10 \mathrm{~min}$ \\
\hline $\begin{array}{l}\text { RAP } \\
\text { (mmHg) }\end{array}$ & $\begin{array}{l}\mathbf{K} \\
\mathbf{S}\end{array}$ & $\begin{array}{l}7.0 \pm 1.7 \\
8.8 \pm 1.8\end{array}$ & $\begin{array}{l}10.2 \pm 2.2 \\
10.8 \pm 1.6\end{array}$ & $\begin{array}{l}14.2 \pm 2.1^{*} \\
11.1 \pm 1.3\end{array}$ & $\begin{array}{l}14.5 \pm 2.0^{*} \\
11.0 \pm 1.5\end{array}$ & $\begin{array}{c}13.3 \pm 1.8^{*} \\
9.6 \pm 1.5\end{array}$ \\
\hline $\begin{array}{l}\text { PCWP } \\
(\mathrm{mmHg})\end{array}$ & $\begin{array}{l}\mathrm{K} \\
\mathrm{S}\end{array}$ & $\begin{array}{l}24.6 \pm 2.0 \\
24.8 \pm 4.5\end{array}$ & $\begin{array}{l}37.3 \pm 3.5^{*} \dagger \\
27.0 \pm 3.5\end{array}$ & $\begin{array}{l}42.4 \pm 2.7^{*} \dagger \\
24.4 \pm 3.8\end{array}$ & $\begin{array}{l}46.7 \pm 2.4^{* \dagger} \\
24.4 \pm 4.3\end{array}$ & $\begin{array}{l}41.3 \pm 2.0^{* \dagger} \\
23.5 \pm 4.4\end{array}$ \\
\hline $\begin{array}{l}\mathrm{HR} \\
\text { (beats } \cdot \min ^{-1} \text { ) }\end{array}$ & $\begin{array}{l}\mathrm{K} \\
\mathbf{S}\end{array}$ & $\begin{array}{l}101 \pm 6 \\
116 \pm 9\end{array}$ & $\begin{array}{l}106 \pm 7 \\
112 \pm 8\end{array}$ & $\begin{array}{l}118 \pm 7^{*} \\
111 \pm 9\end{array}$ & $\begin{array}{l}125 \pm 8^{*} \\
110 \pm 9\end{array}$ & $\begin{array}{l}115 \pm 8^{*} \\
107 \pm 9^{*}\end{array}$ \\
\hline $\begin{array}{l}\text { MAP } \\
(\mathrm{mmHg})\end{array}$ & $\begin{array}{l}K \\
S\end{array}$ & $\begin{array}{l}81 \pm 4 \\
80 \pm 4\end{array}$ & $\begin{array}{l}92 \pm 6 \\
79 \pm 5\end{array}$ & $\begin{array}{c}100 \pm 5^{*} \dagger \\
81 \pm 4\end{array}$ & $\begin{aligned} 101 & \pm 6 * \dagger \\
81 & \pm 5\end{aligned}$ & $\begin{array}{l}99 \pm 7 * \dagger \\
82 \pm 4\end{array}$ \\
\hline $\begin{array}{l}\text { MPAP } \\
\text { (mmHg) }\end{array}$ & $\begin{array}{l}K \\
S\end{array}$ & $\begin{array}{l}34.6 \pm 3 \\
31.1 \pm 4\end{array}$ & $\begin{array}{l}47.4 \pm 4 \dagger \\
34.6 \pm 4\end{array}$ & $\begin{array}{l}52.3 \pm 4^{* \dagger} \\
33.8 \pm 4\end{array}$ & $\begin{array}{l}51.8 \pm 3^{* \dagger} \\
33.3 \pm 4\end{array}$ & $\begin{array}{l}47.4 \pm 3^{*} \dagger \\
32.4 \pm 4\end{array}$ \\
\hline $\begin{array}{l}\mathrm{Cl} \\
\left(\mathrm{L} \cdot \mathrm{min}^{-1} \cdot \mathrm{m}^{-2}\right)\end{array}$ & $\begin{array}{l}K \\
S\end{array}$ & $\begin{array}{l}2.5 \pm 0.2 \\
2.9 \pm 0.2\end{array}$ & $\begin{array}{l}2.0 \pm 0.1^{\dagger} \\
3.0 \pm 0.4\end{array}$ & $\begin{array}{l}1.8 \pm 0.2^{* \dagger} \\
3.0 \pm 0.3\end{array}$ & $\begin{array}{l}2.0 \pm 0.2 * \dagger \\
2.9 \pm 0.4\end{array}$ & $\begin{array}{l}2.0 \pm 0.2 * \dagger \\
2.9 \pm 0.3\end{array}$ \\
\hline $\begin{array}{l}\text { SVR } \\
\left(\text { dyne } \cdot \mathrm{s} \cdot \mathrm{cm}^{-5}\right)\end{array}$ & $\begin{array}{l}K \\
S\end{array}$ & $\begin{array}{l}1411 \pm 116 \\
1147 \pm 101\end{array}$ & $\begin{array}{l}1893 \pm 196 \dagger \\
1112 \pm 151\end{array}$ & $\begin{array}{l}2320 \pm 295^{*} \dagger \\
1102 \pm 109\end{array}$ & $\begin{array}{l}2224 \pm 400^{*} \dagger \\
1136 \pm 110\end{array}$ & $\begin{array}{l}2025 \pm 267^{*} \dagger \\
1203 \pm 113\end{array}$ \\
\hline $\begin{array}{l}\text { SVI } \\
(\mathrm{ml} \cdot \text { beats } \\
\left.-1 \cdot \mathrm{m}^{-2}\right)\end{array}$ & $\begin{array}{l}K \\
S\end{array}$ & $\begin{array}{l}25.9 \pm 3 \\
26.4 \pm 3\end{array}$ & $\begin{array}{l}19.2 \pm 2 * \\
28.0 \pm 4\end{array}$ & $\begin{array}{l}15.7 \pm 2 * \\
28.5 \pm 4\end{array}$ & $\begin{array}{l}16.8 \pm 2 * \\
27.7 \pm 4\end{array}$ & $\begin{array}{l}18.7 \pm 3^{*} \\
28.7 \pm 4\end{array}$ \\
\hline
\end{tabular}

RAP, right atrial pressure; PCWP, pulmonary capillary wedge pressurc; HR, heart rate; MAP, mean arterial pressure; MPAP, mean pulmonary artery pressure; $\mathrm{CI}$, cardiac index; SVR, systemic vascular resistance; SVI, stroke volume index.

All values are mean $\pm S E M$.

${ }^{*} P<0.05$ vs preinduction value.

$\dagger P<0.05$ ketamine vs sufentanil value.

tions in the ketamine group more than doubled $(P<0.5)$. However, the increases in EPI were not consistent (Figures 1 and 2). Plasma concentrations of ANP in the ketamine group were not different from control at any time (Figure 3).

Patients in the sufentanil group remained haemodynamically stable during the study (Table II). Right atrial pressure, PCWP, MAP, MPAP, CI and HR were not different from control at any time. Likewise, plasma NE, EPI and ANP concentrations did not change (Figures 1-3).

There was no difference in the preinduction haemodynamic and chemistry values between the ketamine and sufentanil groups. However, the preinduction norepinephrine, EPI and ANP concentrations were markedly higher than normal values. ${ }^{8.9}$ Plasma ANP values in the treatment groups were not different. After induction of anaesthesia, values for PCWP, Cl, MAP, MPAP, SVR and NE were different in the ketamine and sufentanil groups.

\section{Discussion}

The release of ANP from cardiac atrial myocytes initiates diuretic and natriuretic responses to maintain appropriate fluid and electrolyte balance in the body. In the normal subject distension and stretch of the right atrial myocytes is the stimulus for the secretion of ANP which is synthesized and stored in granules within the myocytes. ${ }^{7}$ Conversely, ANP release in patients with CHF has been shown to correlate more closely with pressure change in the left atrium than in the right. Further ANP release per $\mathrm{mmHg}$ rise in atrial pressure is less than normal in CHF patients, while patients with cardiomyopathy or valve disease release even less ANP per $\mathrm{mmHg}$ pressure increase. ${ }^{9}$ The present study demonstrated a lack of ANP release despite doubling of atrial and pulmonary capillary wedge pressures in patients with end-stage cardiomyopathy. This observation is consistent with the above reports. It would appear that a decline in atrial ANP response to pressure increase parallels a decline in cardiac function. In the study by Matsubara et al. ${ }^{9}$ cardiomyopathy patients were not at end-stage failure requiring heart transplantation as did the patients in this study, and ANP release to increased atrial pressure, although reduced, was still present. The reasons given for the decline in ANP responsiveness were a structural change with extensive replacement of atrial muscle by fibrous tissue, and a diminished elasticity to atrial wall stretch. Depleted ANP stores resulting from the structural alterations was suggested as the cause of the decreased ANP release. Similar findings in animals with experimentally induced cardio- 


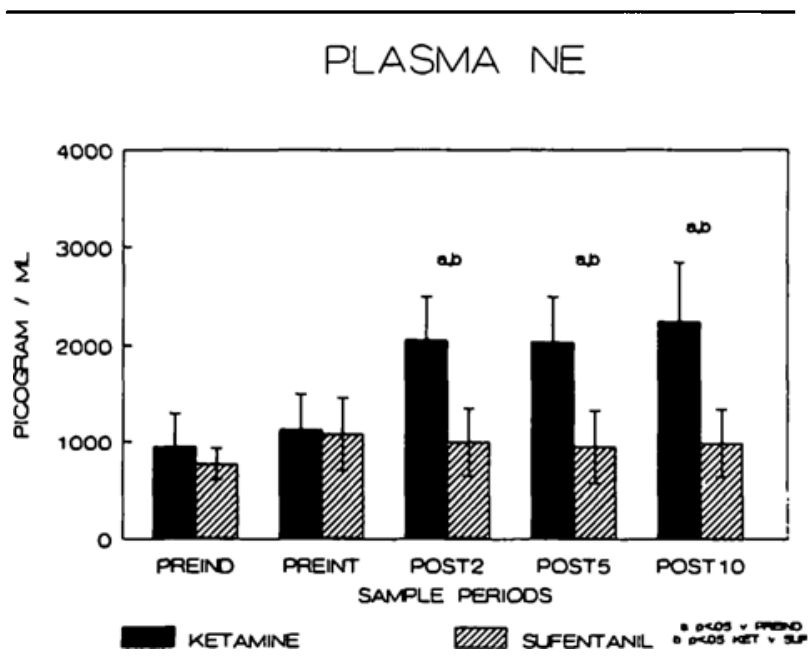

FIGURE I Plasma norepinephrine concentration preinduction, preintubation, and $2,5,10 \mathrm{~min}$ postintubation in cach treatment group. Values are expressed as mean \pm SEM. Statistical differences within and between treatment groups is shown.

myopathies showing ANP in atrial tissue to be depleted has been reported. ${ }^{10,11}$ The elevated preinduction concentration of plasma ANP found in this study was not different from published resting ANP levels in cardiac and transplanted heart patients of 12 to $60 \mathrm{pg} \cdot \mathrm{ml}^{-1} \cdot{ }^{13-18}$ Congestive heart failure patients, on the other hand, have highly elevated resting ANP levels often in the range of $300 \mathrm{pg} \cdot \mathrm{ml}^{-1} \cdot 8 \cdot 19.20 \mathrm{It}$ has been suggested that the increase in circulating ANP initially functions as a compensatory natriuretic response to increased body fluid volume, ${ }^{6.21-23}$ but that over time the responsiveness of the renal receptors to ANP is diminished. ${ }^{14,15}$ It would appear that a positive feedback is established until such time as the atria under chronic elevated pressure undergo structural alteration leading to a reduction in ANP secretion ${ }^{9}$ as was observed in this study.

Patients in the present study had end-stage heart failure with an average ejection fraction of $0.16 \pm 0.02$. In the design of the study the authors took advantage of the acute increase in RAP and PCWP that occurs following ketamine as the stimulus to study ANP release prior to orthotopic heart transplantation. However, the increased atrial pressure that occurs following ketamine may not be equivalent to the increased pressure and stretch that occurs secondary to volume loading, a procedure which we were unable to carry out in these transplant patients. Volume loading is associated with atrial distension, pressure increase and stretch of the myocyte and leads to ANP release. ${ }^{7,13}$ Ketamine on the other hand increases atrial pressure presumably by decreasing cardiac compliance and increasing afterload. Some atrial distension is to be expected due to redistribution of fluid volume to the

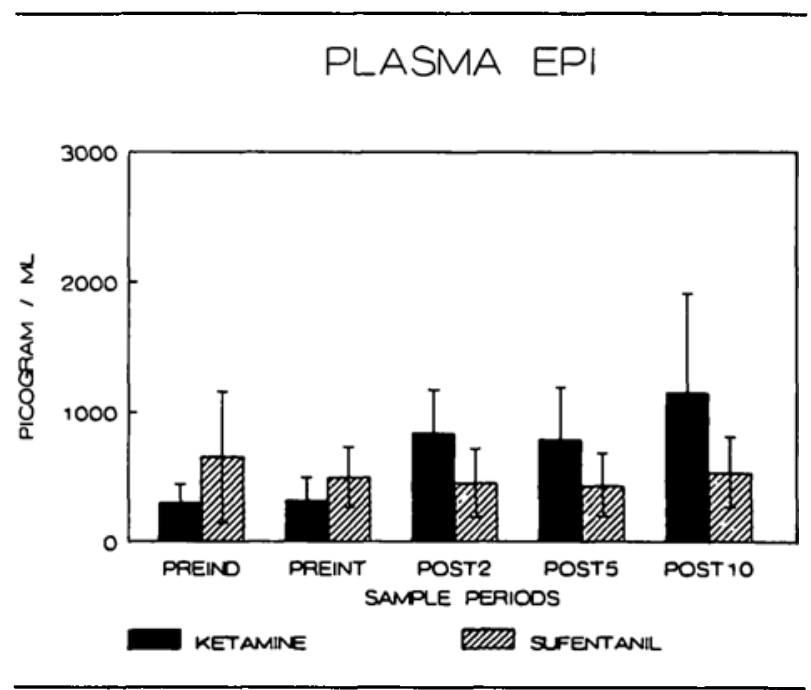

FIGURE 2 Plasma cpinephrine concentrations preinduction, preintubation, and $2,5,10 \mathrm{~min}$ postintubation in each treatment group. Values are expressed as mean \pm SEM. No statistical differences within and between treatment groups were seen.

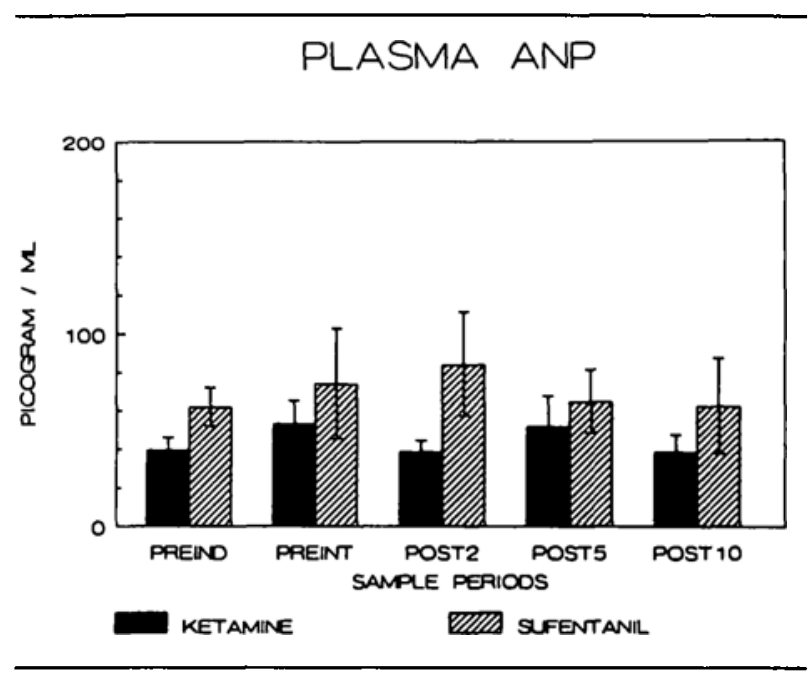

FIGURE 3 Plasma atrial natriuretic peptide concentrations preinduction, preintubation, and 2, 5, $10 \mathrm{~min}$ postintubation in each treatment group. Values are expressed as mean \pm SEM. No statistical differences were seen.

central compartment, but not to the extent of volume loading. The extent of stretch of the myocytes necessary to evoke ANP release is not known. Bates et al. ${ }^{21}$ reported that right atrial pressures greater than $8 \mathrm{mmHg}$ or pulmonary capillary wedge pressures greater than 16 $\mathrm{mmHg}$ were necessary to induce elevated ANP levels in CHF patients. Right atrial and PCWP pressures in the ketamine group were 14 and $37 \mathrm{mmHg}$, respectively. Release of ANP has been reported in man following elevation of the legs, ${ }^{13}$ ventriculoatrial pacing, ${ }^{2}$ and in experimental animals following mitral valve obstruc- 
tion. ${ }^{7}$ Further, infusion of the vasoconstrictor, vasopres$\sin$, into rats was reported to increase right atrial pressure with a significant release of ANP. ${ }^{23}$ These findings suggest that increased atrial pressure secondary to ketamine is sufficient stimulus for ANP release from atrial myocytes.

A second concern is whether ketamine might block the release of ANP. A review of the literature did not offer evidence of ketamine's effect on ANP in man. However, the effect of ketamine and other anaesthetics on ANP in rats has been studied..$^{24}$ Ether, morphine, chloral hydrate and ketamine each more than doubled plasma ANP levels in the rat with morphine causing the greatest increase. Only sodium pentobarbital and urethane were found to decrease plasma ANP levels. Although rat is not man, the response to numerous drugs in rat and man is similar. In light of these findings, it would seem unlikely that the diminished ANP response obtained from the cardiomyopathy patients was due to their receiving ketamine.

Patients with CHF typically show an increase in ANP release with acute volume loading and increased atrial pressure. ${ }^{14,15,19}$ The difference between these reports and the present findings probably reflects the stage of heart failure in the patients studied. Ejection fractions, when reported, were above $37 \%$ compared with $16 \%$ in this study. ${ }^{19}$ Also, the finding of elevated resting plasma catecholamine concentrations (preinduction) in our study is consistent with previous studies of cardiomyopathy patients $^{22,25}$ and of patients with CHF. ${ }^{26,27}$ Norepinephrine is reported to be a stimulus for ANP release in mitral valve and dilated cardiomyopathy patients, but not in normal subjects. ${ }^{9}$ That ANP release was not increased in spite of markedly elevated plasma norepinephrine levels in these transplant patients provides further evidence of their diminished atrial ANP responsiveness.

Based upon these findings and the results of others, the authors propose that a diminution of atrial ANP responsiveness occurs as cardiac failure progresses toward the terminal stage. In the earlier stages of heart failure circulating ANP concentrations and atrial release are increased in conjunction with diminished renal responsiveness to ANP over time. In the case of refractory cardiomyopathies the inability of the atrial myocytes to release ANP in response to acutely increased atrial pressure could reflect an exhaustion of the atrial ANP mechanism following an extended period, often years, of heightened release by the myocytes. In refractory cardiomyopathy patients ANP appears to exert little influence on the control of fluid volume or blood pressure.

In summary, the findings of this study demonstrate that end-stage cardiomyopathy patients do not exhibit increased ANP release in response to acutely increased atrial pressure despite the presence of elevated circulating ANP levels characteristic of heart failure. The dysfunction of the atrial ANP release mechanism appears to parallel the dysfunction of the heart.

\section{Acknowledgements}

The authors would like to thank Lionel Barnes and Peter Lamar for their technical assistance in this study and Kate Stallings for manuscript preparation.

\section{References}

1 Needleman P, Adams SP, Cole BR et al. Atriopeptins as cardiac hormones. Hypertension 1985; 7 : 469-82.

2 Needleman $P$. The expanding physiological roles of atrial natriuretic factor. Nature 1986; 321: 199-200.

3 Genest J. The atrial natriuretic factor. Br Heart J 1986; 56 : 302-16.

4 deBold AJ, Borenstein HB, Veress AT, Sonnenberg HA. A rapid and potent natriuretic response to intravenous injection of atrial myocardial cxtracts in rats. Life Sci 1981; 28: 89-94.

5 Burnett JC, Granger JP, Opgenorth TS. Effects of synthetic atrial factor on renal function and renin release. Am J Physiol 1984; 247: 863-66.

6 Maach T, Camargo MJF, Kleinert HD, Laragh JH, Allas $P$. Atrial natriuretic factor: structure and functional properties. Kidncy Int 1985; 27: 607-15.

7 Ledsome JR, Wilson N, Courneya CA, Rankin AJ. Release of atrial natriuretic peptide by atrial distention. Can J Physiol Pharmacol 1985; 63: 739-42.

8 Hara H, Ogihara T, Shima J et al. Plasma atrial natriuretic peptide level as an index for the severity of congestive heart failure. Clin Cardiol 1987; 10: 437-42.

9 Matsubara $H$, Umeda $Y$, Nishikawa $M$ et al. Heart with circulatory failure secretes and processes atrial natriuretic peptide in a manner different from normal heart. Clin Cardiol 1988; 11: 197-203.

10 Sonnenberg $H$, Milojevic $S$, Chong $C K$, Veress $A T$. Acrial natriuretic factor: reduced cardiac content in spontaneous hypertension rats. Hypertension 1983; 5: 672-5.

11 Chimoskey JE, Spielman WS, Brandt MA, Heidemann $S R$. Cardiac atria of BIO-14.6 hamsters are deficient in natriuretic factor. Science 1984; 223: 820-2.

12 Glisson SN. Investigation of midazolam's influence on physiological and hormonal responses to hypotension. J Cardiovasc Pharmacol 1987; 9: 45-50.

13 Hynynen M, Tikkanen 1, Salmenpera M, Heinonen J, Fyhrquist $F$. Plasma atrial natriuretic peptide concentrations during induction of ancsthcsia and acute volume loading in patients undergoing cardiac surgery. Journal of Cardiothoracic Anesthesia 1987; 1: 401-7. 
14 Cody RJ, Kubo SH, Atlas SA, Laragh JH, Ryman KS, Shaknovich $A$. Direct demonstration of the vasodilator properties of atrial natriuretic factor in normal man and heart failure patients. Clin Res 1986; 34: 476A.

15 Cody RJ, Atlas $S A$, Laragh $J H$ et al. Atrial natriuretic factor in normal subjects and heart failure patients. J Clin lnvest 1986; 78: 1362-74.

16 Flezzani P, McIntyre W, Xuan YT, Su YF, Leslie JB, Watkins WD. Atrial natriurctic peptide plasma levels during cardiac surgery. Joumal of Cardiothoracic Anesthesia 1988; 2: 274-80.

17 Deray G, Maistre G, Cacoub P et al. Plasma concentrations of atrial natriuretic peptide in patients with artificial and transplanted hearts. Eur J Clin Pharmacol 1988; 34: 91-3.

18 Singer DJR, Bucklley MG, Gregror GA, Khaghani A, Banner NR, Yacoub $M H$. Raised concentrations of plasma atrial natriurctic peptides in cardiac transplant recipients. BMJ 1986; 293: 1391-2.

19 Shenker Y, Sider RS, Ostafin EA, Grekin RJ. Plasma levels of immunoreactive atrial natriuretic factor in healthy subjects and in patients with edema. J Clin Invest 1985; 76: 1684-7.

20 Raine AEG, Erne $P$, Burgisser $E$ et al. Atrial natriuretic peptide and atrial pressure in patients with congestive heart failurc. N Engl J Med 1986; 315: 533-7.

21 Bates ER, Shenker Y, Grekin RJ. The relationship between plasma levels of immunoreactive atrial natriuretic hormone and hemodynamic function in man. Circulation 1986; 73: 1155-61.

22 Weber KT, Janicki JS, Likoff MJ, Shroff SG, Andrews $V$. Chronic cardiac failure: pathophysiology and therapeutic considerations. Triangle 1983; 22: 1-9.

23 Needleman P. Greemwald JE. Atropeptin: a cardiac hormone intimately involved in fluid, electrolyte, and blood-pressure homeostasis. N Engl J Med 1986; 314 : 828-34

24 Horky K, Gutkowska J, Garcia R, Thibault G, Genest J, Cantin $M$. Effect of different anesthetics on immunoreactive atrial natriuretic factor concentrations in rat plasma. Biochem Biophys Res Comm 1985; 129: 651-7.

25 Anand IS, Ferrari R, Kalra GS, Wahi PL, Poole-Wilson $P A$, Harris $P C$. Edema of cardiac origin: studics of body water and sodium, renal function, hemodynamic indexes, and plasma hormones in untreated congestive cardiac failure. Circulation 1989; 80: 299-305.

26 Thomas JA, Marks BH. Plasma norepinephrine in congestive heart failure. Am J Cardiology 1978; 41: 233-43.

27 Goldstein DS. Plasma norepinephrine as an indicator of sympathetic neural activity in clinical cardiology. Am J Cardiology 1981; 48: 1147-54. 